\title{
MEDIA PEMBELAJARAN RAWAT TANAMAN HIDROPONIK BERBASIS MOBILE ANDROID
}

\author{
Taufik Kurnialensya \\ Desain Grafis,STEKOM \\ Jl. Majapahit 605 Pedurungan Semarang 50193 \\ E-mail :taufik@stekom.ac.id
}

\begin{abstract}
ABSTRAK
Perkembangan teknologi berbasis mobile android sangat berpengaruh didalam kehidupan manusia. Teknologi mobile android sudah banyak digunakan manfaatnya dalam berbagai bidang, salah satunya pemanfaatannya didalam bidang pertanian yaitu sebagai media pembelajaran rawat tanaman hidroponik. Didalam media pembelajaran rawat tanaman hidroponik berbasis mobile android memiliki banyak manfaatnya, salah satunya menjadikan pemakai menjadi mandiri dalam rawat tanaman hidroponik. Media pembelajaran rawat tanaman hidroponik didalamnya terdapat paparan-paparan materi tentang rawat tanaman hidroponik, pengenalan terhadap jenis tanaman, penanganan penyakit dan hama, dan kuis yang berisikan tentang materi-materi berkaitan dengan rawat tanaman hidroponik. Dari hasil penelitian ini adalah menghasilkan aplikasi media pembelajaran rawat tanaman hidroponik berbasis mobile android yang lebih friendly untuk pemula dalam belajar bertanam tanaman hidroponik. Dari hasil kuisioner yang telah dilakukan mendapat nilai aspek rekayasa perangkat lunak sebesar 82\%, berkaitan dengan aspek desain pembelajaran sebesar 80\%, berkaitan aspek komunikasi visual sebesar $82 \%$.
\end{abstract}

Kata Kunci: media pembelajaran, hidroponik, mobile android

\begin{abstract}
The development of mobile android-based technology is very influential in human life. Android mobile technology has been widely used its benefits in various fields, one of which is its use in agriculture, namely as a medium for hydroponic plant care. In the hydroponic plant-based learning media based on mobile android has many benefits, one of which makes the user become independent in the care of hydroponic plants. Learning media for hydroponic plant care consists of material exposures about hydroponic plant care, introduction to types of plants, handling diseases and pests, and quizzes that contain material related to hydroponic plant care. From the results of this study is to produce an application of learning media for hydroponic plant care based on Android Mobile that is more friendly for beginners in learning to grow hydroponic plants. From the results of the questionnaire that has been done get a value of the aspect of software engineering by $82 \%$, relating to the aspects of learning design by $80 \%$, relating to aspects of visual communication by $82 \%$.
\end{abstract}

Keywords: learning media, hydroponics, mobile android

\section{PENDAHULUAN}

\subsection{Latar Belakang}

Peran teknologi terhadap pendidikan sangat

membantu kegiatan-kegiatan pembelajaran.

Beberapa alat tersebut misalnya Overhead Projector

(OHP), penggunaan komputer desktop atau laptop yang disambungkan ke Liquid Crystal Display (LCD) monitor dan projector. Munculnya alat bantu dalam teknologi pendidikan tersebut membawa nuansa baru, terutama dalam pelaksanaan proses pembelajaran. Sambutan masyarakat para pengguna teknologi pendidikan sangat besar, sehingga dalam waktu yang tidak terlalu lama teknologi ini sudah begitu familiar dalam membantu kelancaran pelaksanaan pendidikan dan pembelajaran.

Perkembangan handphone pada saat ini telah memasuki era smartphone dengan berbagai kelebihannya. Smartphone hadir dengan berbagai fitur yang menarik yang akan membantu layaknya sebuah komputer dekstop. Saat ini penggunaan handphone belum dimanfaatkan secara maksimal dalam dunia pendidikan. Terlihat pemanfaatan smartphone dalam proses pembelajaran masih sangat minim. Bagi masyarakat umum, khususnya bagi remaja smartphone lebih sering digunakan untuk berkirim pesan, serta menyambangi situs-situs jejaring sosial. Smartphone sekarang ini juga dibekali dengan berbagai macam sistem operasi salah satunya mobile android.

Perkembangan teknologi berbasis mobile android sangat berpengaruh didalam kehidupan manusia. Teknologi mobile android sudah banyak digunakan manfaatnya dalam berbagai bidang, salah satunya pemanfaatannya didalam bidang pertanian yaitu sebagai media pembelajaran rawat tanaman hidroponik. Didalam media pembelajaran rawat 
tanaman hidroponik berbasis mobile android memiliki banyak manfaatnya, salah satunya menjadikan pemakai menjadi mandiri dalam bercocok tanaman dengan media hidroponik. Media pembelajaran rawat tanaman hidroponik didalamnya terdapat paparan-paparan materi tentang rawat tanaman hidroponik, pengenalan terhadap jenis tanaman, penanganan penyakit dan hama, dan kuis yang berisikan tentang materi-materi berkaitan dengan rawat tanaman hidroponik.

Budidaya tanaman secara hidroponik adalah dengan memanfaatkan perangkat teknologi informasi dan komunikasi. Pengunaan perangkat mobile dengan aplikasi android dirasa tepat untuk digunakan dalam proses pembelajaran, karena penggunaan aplikasi berbasis android dapat memberikan pengalaman baru mengenai pemanfaatan teknologi informasi dan komunikasi, serta memberikan kesempatan kepada masyarakat untuk dapat belajar secara lebih mandiri dalam bercocok tanam secara hidroponik.

\subsection{Rumusan Masalah}

Berdasarkan latar belakang masalah di atas maka didapat rumusan masalah sebagai berikut:

a. Apakah penerapan aplikasi android sebagai media pembelajaran budidaya tanaman hidroponik bisa membantu masyarakat dalam bertanam secara hidroponik?

b. Apakah media pembelajaran rawat tanaman hidroponik mudah dipahami dan digunakan masyarakat?

\subsection{Tujuan Penelitian}

Tujuan dari penelitian ini adalah untuk :

a. Membuat media pembelajaran berbasis mobile android sebagai upaya membantu masyarakat dalam bertanam tanaman secara hidroponik

b. Membuat media pembelajaran rawat tanaman secara hidroponik yang mudah dipahami dan digunakan untuk masyarakat.

\subsection{Referensi}

a. Media Audio

Media audio yaitu suatu alat media yang isi pesannya hanya dapat diterima melalui indera pendengaran saja. Pengertian lain menjelaskan bahwa media audio untuk pengajaran adalah bahan yang mengandung pesan dalam bentuk auditif (pita suara/piringan suara), yang dapat merangsang pikiran, perasaan, perhatian \& kemauan sisiwa sehingga terjadi proses belajar mengajar (Sudjana \& Rivai, 2003)

b. Media Visual

Media Visual artinya semua alat peraga yang digunakan dalam proses belajar yang bisa dinikmati lewat panca-indera mata (Daryanto, 1993). Media Visual yang bergerak ialah media yang dapat menampilkan atau membiaskan gambar atau bayangan yang dapat bergerak di layar bias, seperti: bias gambar-gambar yang ditampilkan oleh motion picture film dan loop film

c. Media Audio Visual

Media audio visual adalah sejumlah peralatan yang dipakai oleh para guru dalam menyampaikan konsep, gagasan dan pengalaman yang ditangkap oleh indera pandang dan pendengaran. Berdasarkan pengertian-pengertian yang telah diberikan, maka media audiovisual adalah media penyalur pesan dengan memanfaatkan indera pendengaran dan penglihatan (Sudjana \& Rivai, 2003). Jenis media ini mempunyai kemampuan yang lebih baik, karena meliputi kedua jenis media auditif (mendengar) dan visual (melihat).

d. Pembelajaran

Pembelajaran adalah proses interaksi peserta didik dengan pendidik dan sumber belajar pada suatu lingkungan belajar yang meliputi guru dan siswa yang saling bertukar informasi. Pengertian pembelajaran adalah suatu sistem yang bertujuan untuk membantu proses belajar mahasiswa, yang berisi serangkaian peristiwa yang dirancang, disusun sedemikian rupa untuk mempengaruhi dan mendukung terjadinya proses belajar mahasiswa yang bersifat internal (Gegne \& Briggs, 1979), sedangkan menurut Kamus Besar Bahasa Indonesia (KBBI), pembelajaran diidentikkan dengan kata "mengajar" berasal dari kata "ajar" yang berarti petunjuk yang diberikan kepada orang supaya diketahui (diturut) ditambah denga awalan "pe" dan akhiran "an" menjadi "pembelajaran", yang berarti proses, perbuatan, cara mengajar atau mengajarkan sehingga anak didik mau belajar (Alwi, 2003).

e. Media Pembelajaran

Gagne' dan Briggs (Arsyad, 2011), secara implisit mengatakan bahwa media pembelajaan meliputi alat yang secara fisik digunakan untuk menyampaikan isi materi pengajaran yang terdiri dari antara lain buku, tape recorder, kaset, video camera, video recorder, film, slide (gambar bingkai), foto, gambar, grafik, televisi dan komputer. Dengan kata lain media adalah komponen sumber belajar atau wahana fisik yang mengandung materi instruksional di lingkungan siswa yang dapat merangsang siswa untuk belajar.

f. Android

Android (sistem operasi) - OS Android Merupakan sebuah sistem operasi yang berbasis Linux untuk telepon seluler seperti telepon pintar dan komputer tablet. Android menyediakan platform terbuka bagi para pengembang untuk menciptakan aplikasi mereka sendiri untuk digunakan oleh bermacam peranti bergerak. (Yuniar Supardi, 2014) 
g. Hidroponik

Hidroponik adalah metode penanaman tanaman tanpa menggunakan media tumbuh dari tanah. Hidroponik berarti penanaman dalam air yang mengandung campuran hara. Pengertian hidroponik yang dikemukaan oleh (Lingga, 2002) adalah istilah yang digunakan untuk menjelaskan tentang cara bercocok tanam tanpa menggunakan tanah sebagai media pertanamannya. Hidroponik tidak terlepas dari penggunaan media tumbuh lain yang bukan tanah sebagai penopang pertumbuhan tanaman. Sistem hidroponik merupakan cara produksi tanaman yang sangat efektif, sistem ini dikembangkan berdasarkan alasan bahwa jika tanaman diberi kondisi pertumbuhan yang optimal, maka potensi maksimum untuk berproduksi dapat dicapai.

\section{PEMBAHASAN}

\subsection{Metode Penelitian}

Penelitian ini merupakan penelitian Riset dan Pengembangan (R\&D) dengan Model pengembangan Borg and Gall (1987: 775) dengan 6 langkah. Meliputi:

a. Potensi merupakan segala sesuatu yang bila didayagunakan akan memiliki nilai tambah. Masalah merupakan penyimpangan antara yang diharapkan dengan yang terjadi dalam hal ini masalah yang terjadi adalah :

1. Apakah penerapan aplikasi android sebagai media pembelajaran budidaya tanaman hidroponik bisa membantu masyarakat dalam bertanam secara hidroponik?

2. Apakah media pembelajaran rawat tanaman hidroponik mudah dipahami dan digunakan masyarakat?

b. Pengumpulan Data

Dalam pengumpulan data disini penulis mendapatkan informasi dari buku, jurnal, literature yang berkaitan dengan media pembelajaran dan tanaman hidroponik.

c. Desain Produk

Dalam langkah ini penulis melakukan mendesain produk yag diwujudkan dalam bentuk gambar atau bagan sehingga dapat digunakan sebagai pegangan untuk menilai dan membuatnya. Hasil akhir ini berupa desain produk yang baru yang dilengkap dengan spesifikasinya. Langkah desain produk dengan membuat.
1. Layout Pembukaan

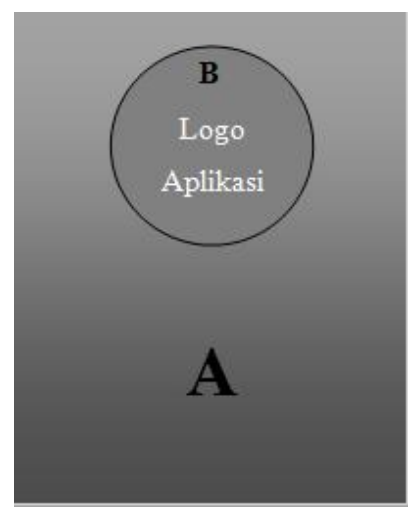

Gambar 1. Layout Pembukaan

Keterangan Gambar 1 :

Tampilan pembukaan slide 1, yaitu berisi tentang nama aplikasi yang dibuat beserta logo. A : Latar belakang

B : Logo aplikasi 3D bergerak

2. Layout Login

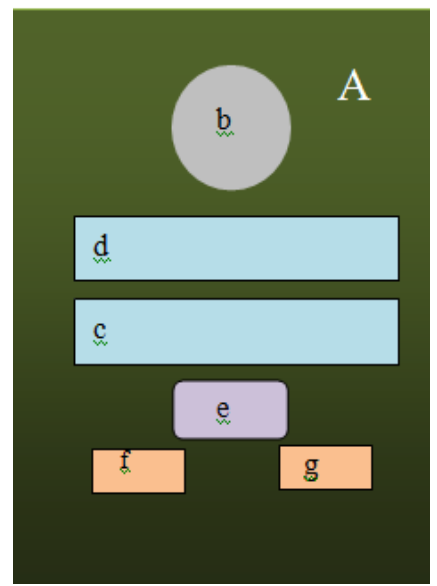

Gambar 2. Layout Login

Keterangan gambar 2 :
A : Latar Belakang
b : Logo 3D bergerak
c : Alamat Email
d : Password Email
e : Tombol "Masuk"
f : Tombol "Daftar Baru"
g : Tombol "Lupa Password 
3. Halaman Menu

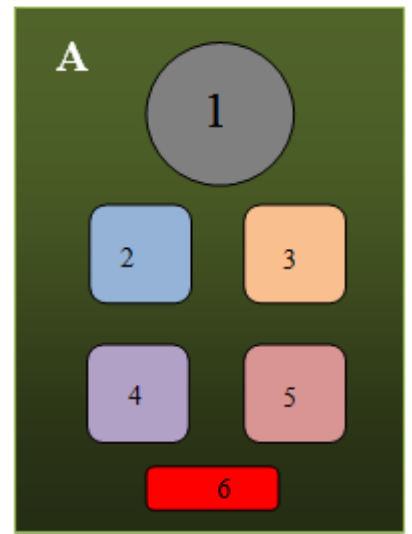

Gambar 3. Halaman Menu

Keterangan gambar 3 :

A : Latar Belakang

1 : Logo 3D bergerak

2: Link menuju ke Materi 1.

3 : Link menuju ke Materi 2.

4 : Link menuju ke Materi 3.

5 : Link menuju ke Latihan Soal.

6 : Tombol "Keluar".

4. Halaman Menu

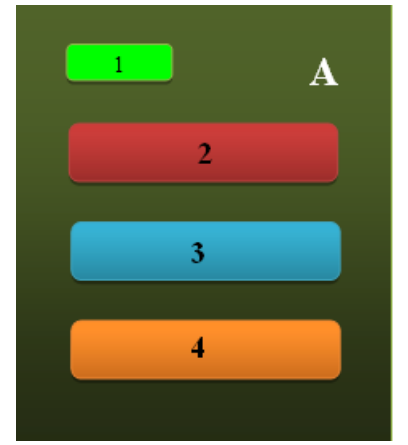

Gambar 4. Halaman Menu

Keterangan gambar 4 :

A : Latar Belakang

1 : Tombol "Kembali"

2 : Sejarah Hidroponik

3 : Latar Belakang Hidroponik

4 : Prinsip Tanaman Hidroponik

5. Halaman Materi 1

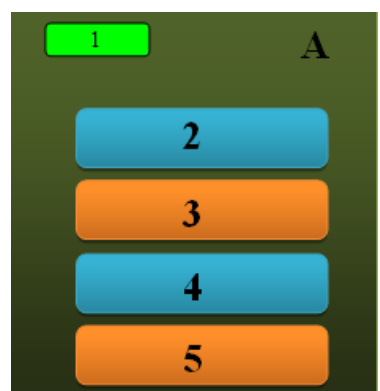

Gambar 5. Halaman Menu
Keterangan gambar 5 :
A : Latar Belakang
1 : Tombol "Kembali"
2 : Media Tanam
3 : Jenis Tanamaan Buah
4 : Jenis Tanaman Sayur
5 : Jenis Tanaman Bunga

6. Halaman Penjelasan Media Tanam

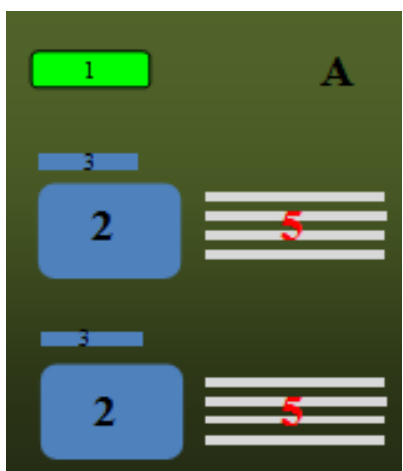

Gambar 6. Halaman Penjelasan Media Tanam

Keterangan gambar 6 :

A : Latar Belakang

1 : Tombol "Kembali"

2 : Gambar Media Tanam

3 : Nama Media Tanam

5 : Penjelasan tentang Media Tanam

7. Halaman Latihan Kuis

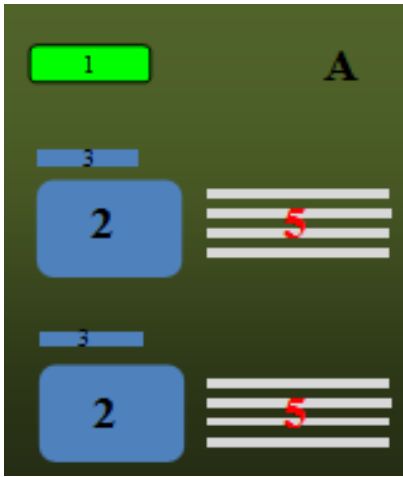

Gambar 7. Halaman Penjelasan Media Tanam

Keterangan gambar 7 :

A : Latar Belakang

1 : Tombol "Kembali"

2 : Gambar Media Tanam

3 : Nama Media Tanam

5 : Penjelasan tentang Media Tanam 
8. Halaman Latihan Kuis

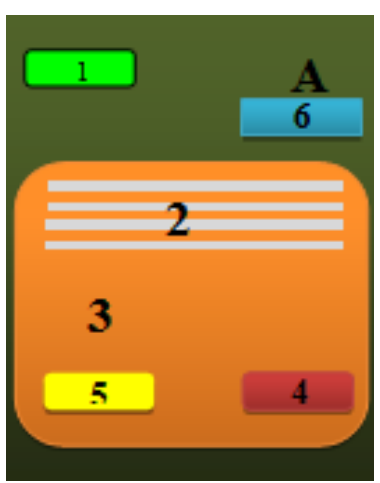

Gambar 8. Halaman Latihan Kuis

Keterangan gambar 8 :

A : Latar Belakang

1 : Tombol "Kembali"

2 : Soal

3 : Pilihan Ganda

4 : Tombol "Lanjutkan"

5 : Tombol "Kembali"

6 : Waktu mengerjakan

9. Tabel Pemakai

Tabel pemakai memiliki kunci field kdpemakai.

\section{Tabel 1. Tabel Pemakai}

\begin{tabular}{|l|l|l|l|}
\hline Field & Type & Size & Ket \\
\hline Kdpemakai & Char & 20 & Kunci \\
\hline Nama & Char & 50 & \\
\hline Email & Char & 50 & \\
\hline Password & Char & 80 & \\
\hline Gender & Text & & \\
\hline
\end{tabular}

10. Tabel Bank Soal

Tabel Bank Soal memiliki kunci field soalid.

Tabel 2. Tabel Bank Soal

\begin{tabular}{|l|l|l|l|}
\hline Field & Type & Size & Ket \\
\hline Soalid & Char & 15 & Kunci \\
\hline Pertanyaan & Text & & \\
\hline Pilihan1 & Char & 100 & \\
\hline Pilihan2 & Char & 100 & \\
\hline Pilihan3 & Char & 100 & \\
\hline Pilihan4 & Char & 100 & \\
\hline Jawaban & Char & 5 & \\
\hline Gambar & Char & 100 & \\
\hline Kdmateri & Char & 25 & \\
\hline Level & Char & 5 & \\
\hline
\end{tabular}

11. Tabel Nilai

Tabel nilai memiliki kunci field kdnilai.

Tabel 3. Tabel Nilai

\begin{tabular}{|l|l|l|l|}
\hline Field & Type & Size & Ket \\
\hline kdnilai & Char & 15 & Kunci \\
\hline kdpemakai & Char & 25 & \\
\hline Benar & Char & 5 & \\
\hline Salah & Char & 5 & \\
\hline Kosong & Char & 5 & \\
\hline Nilai & Char & 5 & \\
\hline Tanggal & Date & & \\
\hline Level & Char & 20 & \\
\hline
\end{tabular}

12. Tabel Admin

Tabel Admin memiliki kunci field kdadmin.

Tabel 3. Tabel Nilai

\begin{tabular}{|l|l|l|l|}
\hline Field & Type & Size & Ket \\
\hline kdadmin & Char & 15 & Kunci \\
\hline nama & Char & 50 & \\
\hline username & Char & 50 & \\
\hline password & Char & 50 & \\
\hline gambar & Text & & \\
\hline
\end{tabular}

d. Validasi Desain

Validasi desain merupakan proses kegiatan untuk menilai apakah rancangan produk sudah maksimal dan layak untuk digunakan

e. Revisi Desain

Dalam tahap ini seorang pakar melakukan validasi dari desain yang dihasilkan, jika tidak sesuai dengan tujuan awal maka peneliti akan melakukan perbaikan atau merevisi sesuai yang diminta oleh pakar.

f. Uji Coba Produk

Uji coba produk dilakukan setelah divalidasi dan direvisi oleh pakar. Jika dalam uji coba hasil yang dihasilkan dapat menjawab dan menyeleaikan permasalahan yang ada maka produk software akan siap digunakan.

1. Halaman Login

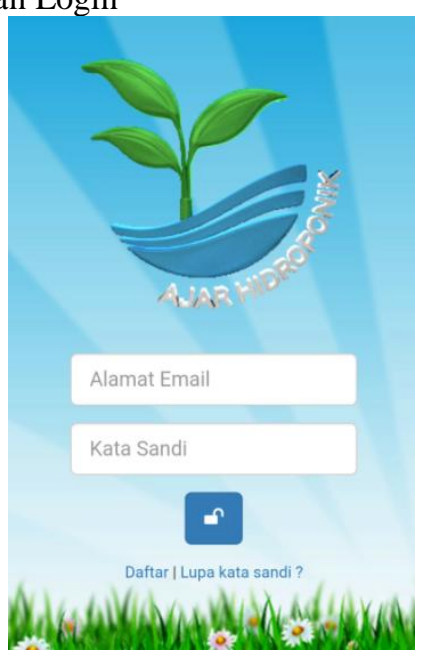

Gambar 9. Halaman Login 
Keterangan gambar 9 :

Halaman login merupakan halaman digunakan user untuk masuk kedalam sistem.

2. Pendaftaran User

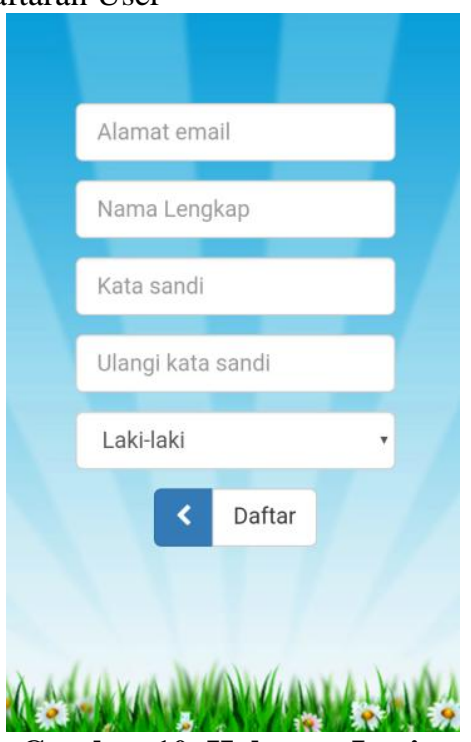

Gambar 10. Halaman Login

Keterangan gambar 10 :

Halaman pendaftaran user merupakan halaman yang digunakan oleh pemakai untuk pendaftaran pemakai baru.

3. Menu Materi

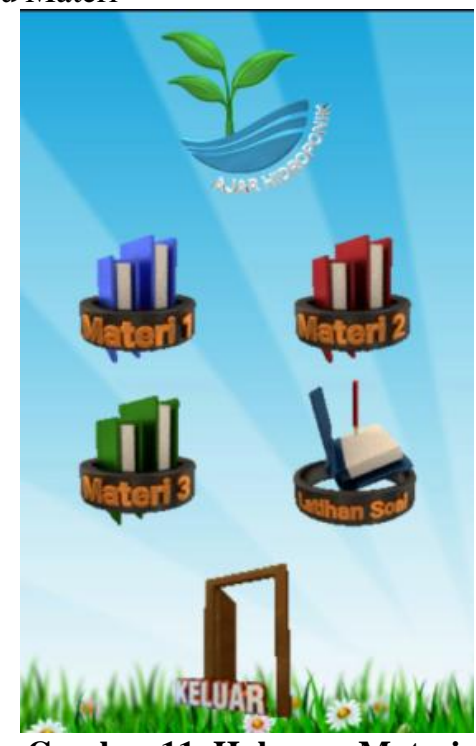

Gambar 11. Halaman Materi

Keterangan gambar 11 :

Halaman materi merupakan halaman yang menampilkan beberapa menu materi yang berkaiatan dengan hidroponik
4. Menu Sub Materi

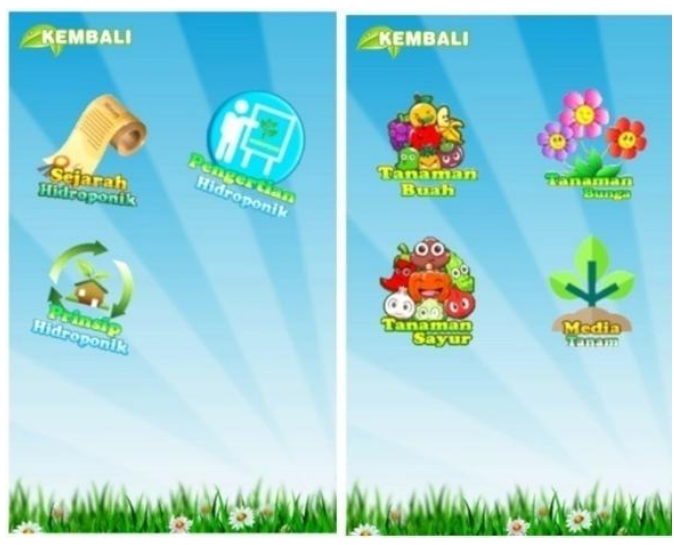

Gambar 12. Halaman Sub Materi

Keterangan gambar 12 :

Halaman sub materi merupakan halaman yang menampilkan beberapa sub materi yang berkaiatan dengan hidroponik

5. Menu Latihan Kuis

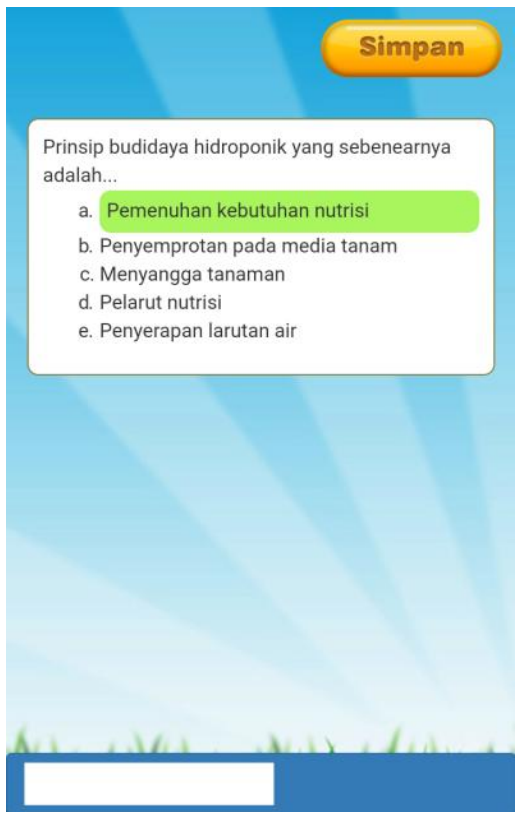

Gambar 13. Halaman Latihan Kuis

Keterangan gambar 13 :

Halaman latihan kuis merupakan halaman yang menampilkan soal latihan soal 
6. Menu Video Tutorial

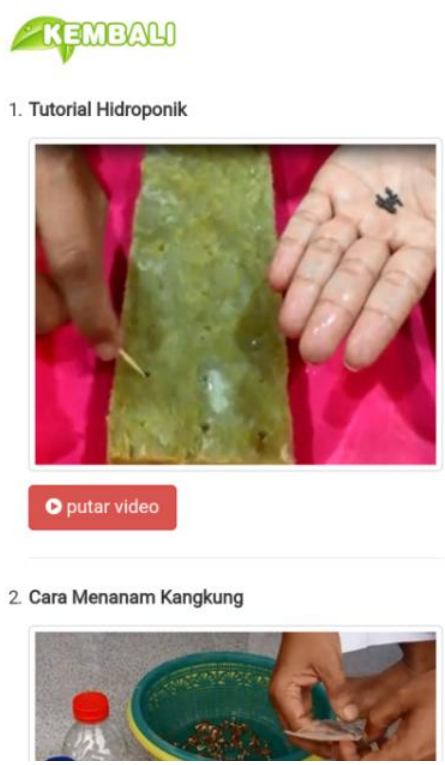

Gambar 14. Halaman Video Tutorial

Keterangan gambar 14 :

Halaman video tutorial merupakan halaman yang menampilkan video tutorial bagaimana cara bertanam secara hidroponik.

7. Form Bank Soal

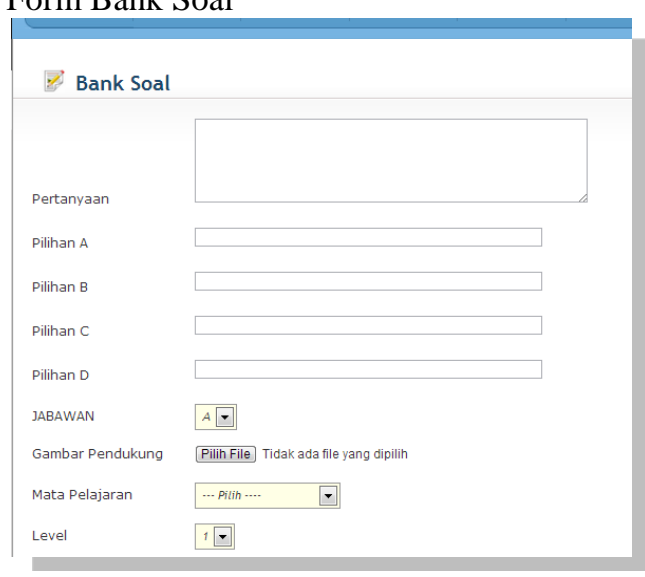

\section{Gambar 15. Bank Soal}

Keterangan gambar 15 :

Halaman bank soal merupakan halaman yang digunakan untuk memasukkan data soal latihan kuis.

\subsection{Hasil Validasi}

Untuk mengetahui hasil yang dicapai maka diperlukan kuisioner untuk 20 orang penilai dengan memberikan pertanyaan yang disajikan pada Tabel 4 sebagai berikut :
Tabel 4. Pertanyaan Untuk Responden

\begin{tabular}{|l|l|l|}
\hline No & Pertanyaan & Jawaban \\
\hline 1 & Keindahan tampilan produk & 1. Kurang \\
\hline 2 & Kemudahan penggunaan & 3. Baik \\
\hline 3 & Keterbacaan teks & $\begin{array}{l}\text { 4. Sangat } \\
\text { baik } \\
\text { jelas }\end{array}$ \\
\hline 5 & Kejelasan tampilan foto & \\
\hline 6 & $\begin{array}{l}\text { Kemudahan pemahaman materi } \\
\text { dalam bentuk foto dan teks }\end{array}$ & \\
\hline 7 & $\begin{array}{l}\text { Kejelasan gambar pada video } \\
\text { tutorial }\end{array}$ & \\
\hline 8 & $\begin{array}{l}\text { Kejelasan suara pada video } \\
\text { tutorial }\end{array}$ & \\
\hline 9 & $\begin{array}{l}\text { Kemudahan pemahaman video } \\
\text { tutorial }\end{array}$ & \\
\hline 10 & $\begin{array}{l}\text { Kemudahan login pada soal } \\
\text { evaluasi }\end{array}$ \\
\hline
\end{tabular}

Dari hasil pengujian melalui angket yang berjumlah 10 pertanyaan dan diberikan oleh 20 orang responden, nilai yang diperoleh:

Tabel 5. Nilai Responden

\begin{tabular}{|c|c|c|c|c|c|}
\hline \multirow{2}{*}{ Responden } & \multicolumn{4}{|c|}{ Nilai } & \multirow{2}{*}{ Jumlah } \\
\hline & 1 & 2 & 3 & 4 & \\
\hline 1 & 0 & 1 & 6 & 3 & 32 \\
\hline 2 & 0 & 0 & 8 & 2 & 32 \\
\hline 3 & 0 & 0 & 8 & 2 & 32 \\
\hline 4 & 0 & 0 & 7 & 3 & 33 \\
\hline 5 & 0 & 0 & 9 & 1 & 31 \\
\hline 6 & 0 & 0 & 6 & 4 & 34 \\
\hline 7 & 0 & 1 & 5 & 4 & 31 \\
\hline 8 & 0 & 0 & 7 & 3 & 33 \\
\hline 9 & 0 & 1 & 7 & 2 & 31 \\
\hline 10 & 0 & 2 & 6 & 2 & 30 \\
\hline 11 & 0 & 1 & 5 & 4 & 31 \\
\hline 12 & 0 & 0 & 7 & 3 & 33 \\
\hline 13 & 0 & 1 & 7 & 2 & 31 \\
\hline 14 & 0 & 0 & 8 & 2 & 32 \\
\hline 15 & 0 & 1 & 6 & 3 & 32 \\
\hline 16 & 0 & 1 & 7 & 2 & 31 \\
\hline 17 & 0 & 0 & 8 & 2 & 32 \\
\hline 18 & 0 & 1 & 6 & 3 & 32 \\
\hline 19 & 0 & 2 & 6 & 2 & 30 \\
\hline 20 & 0 & 1 & 7 & 2 & 31 \\
\hline & Jum & $\mathrm{T}$ & & & 634 \\
\hline
\end{tabular}

Sehingga dapat dihitung nilai respondennya :

$$
\begin{aligned}
& \sum^{\chi} \text { responden }=\frac{\text { Jumlah total nilai responden }}{\text { Jumlah responden }} \\
& \sum^{\chi} \text { responden }=\frac{634}{20}
\end{aligned}
$$




\section{$\sum^{\chi}$ responden $=31,7$}

Maka diperoleh nilai validasi dari responden sebagai berikut :

$\sum^{\chi}$ user $=\frac{\sum^{\text {xresponden }}}{\mathrm{N}}$

$\sum^{\chi}$ user $=\frac{31,7}{10}$

$\sum^{\chi}$ user $=3,17$

Data nilai kelayakan yang menggunakan media pembelajaran diperoleh nilai 3,17 yang dapat digolongkan valid.

Tabel 6. Penilaian RPL

\begin{tabular}{|c|c|c|}
\hline No & Aspek Penilaian RPL & Nilai \\
\hline 1 & $\begin{array}{l}\text { Efektif dan efisien dalam } \\
\text { pengembangan maupun penggunaan } \\
\text { media pembelajaran }\end{array}$ & 8 \\
\hline 2 & Reliable (handal) & 7 \\
\hline 3 & $\begin{array}{l}\text { Maintainable (dapat } \\
\text { dipelihara/dikelola dengan mudah) }\end{array}$ & 8 \\
\hline 4 & $\begin{array}{l}\text { Usabilitas (mudah digunakan dan } \\
\text { sederhana dalam pengoperasiannya) }\end{array}$ & 9 \\
\hline 5 & $\begin{array}{l}\text { Ketepatan pemilihan jenis } \\
\text { aplikasi/software/tool } \\
\text { pengembangan }\end{array}$ & 8 \\
\hline 6 & $\begin{array}{l}\text { Kompatibilitas (media pembelajaran } \\
\text { dapat diinstalasi/dijalankan di } \\
\text { berbagai hardware dan software } \\
\text { yang ada) }\end{array}$ & 8 \\
\hline 7 & $\begin{array}{l}\text { Pemaketan program media } \\
\text { pembelajaran terpadu dan mudah } \\
\text { dalam eksekusi }\end{array}$ & 8 \\
\hline 8 & $\begin{array}{l}\text { Dokumentasi program media } \\
\text { pembelajaran yang lengkap meliputi: } \\
\text { petunjuk instalasi (jelas, singkat, } \\
\text { lengkap), trouble shooting (jelas, } \\
\text { terstruktur, dan antisipatif), desain } \\
\text { program (jelas, menggambarkan alur } \\
\text { kerja program) }\end{array}$ & 9 \\
\hline 9 & $\begin{array}{lr}\text { Reusable (sebagian atau seluruh } \\
\text { program media pembelajaran } & \text { dapat } \\
\text { dimanfaatkan kembali } & \text { untuk } \\
\text { mengembangkan } & \text { media } \\
\text { pembelajaran lain) } & \\
\end{array}$ & 8 \\
\hline 10 & Terstruktur & 9 \\
\hline \multicolumn{2}{|c|}{ Jumlah Nilai } & 82 \\
\hline
\end{tabular}

Tabel 7. Penilaian Desain Pembelajaran

\begin{tabular}{|l|l|l|}
\hline No & Aspek Penilaian Desain Pembelajaran & Nilai \\
\hline 1 & $\begin{array}{l}\text { Kejelasan tujuan pembelajaran } \\
\text { (rumusan, realistis) }\end{array}$ & 8 \\
\hline 2 & $\begin{array}{l}\text { Relevansi tujuan pembelajaran } \\
\text { dengan SK/KD/Kurikulum }\end{array}$ & 7 \\
\hline 3 & $\begin{array}{l}\text { Cakupan dan kedalaman tujuan } \\
\text { pembelajaran }\end{array}$ & 8 \\
\hline 4 & Ketepatan penggunaan strategi & 7 \\
\hline
\end{tabular}

\begin{tabular}{|l|l|l|}
\hline & pembelajaran & \\
\hline 5 & Interaktivitas & 8 \\
\hline 6 & Kontekstualitas dan aktualitas & 8 \\
\hline 7 & $\begin{array}{l}\text { Kelengkapan dan kualitas bahan } \\
\text { bantuan belajar }\end{array}$ & 8 \\
\hline 8 & $\begin{array}{l}\text { Kesesuaian materi dengan tujuan } \\
\text { pembelajaran }\end{array}$ & 9 \\
\hline 9 & $\begin{array}{l}\text { Konsistensi evaluasi dengan tujuan } \\
\text { pembelajaran }\end{array}$ & 9 \\
\hline 10 & $\begin{array}{l}\text { Pemberian umpan balik terhadap } \\
\text { hasil evaluasi }\end{array}$ & 8 \\
\hline \multicolumn{1}{|c|}{ Jumlah Nilai } & 80 \\
\hline
\end{tabular}

Tabel 8. Penilaian Komunikasi Visual

\begin{tabular}{|c|c|c|}
\hline No & Aspek Penilaian Komunikasi Visual & Nilai \\
\hline 1 & $\begin{array}{l}\text { Komunikatif; sesuai dengan } \\
\text { pesan dan dapat diterima/sejalan } \\
\text { dengan keinginan sasaran }\end{array}$ & 8 \\
\hline 2 & $\begin{array}{l}\text { Kreatif dalam ide berikut } \\
\text { penuangan gagasan }\end{array}$ & 7 \\
\hline 3 & $\begin{array}{l}\text { Audio (narasi, sound effect, } \\
\text { backsound,musik) }\end{array}$ & 9 \\
\hline 4 & $\begin{array}{ll}\text { Visual (layout } & \text { design, } \\
\text { typography, warna) } & \end{array}$ & 9 \\
\hline 5 & $\begin{array}{lll}\text { Layout } & \text { Interactive } & \text { (ikon } \\
\text { navigasi) } & & \\
\end{array}$ & 8 \\
\hline \multicolumn{2}{|r|}{ Jumlah Nilai } & $41 \times 2=82$ \\
\hline
\end{tabular}

\section{KESIMPULAN}

Berdasarkan hasil penelitian media pembelajaran rawat tanaman hidroponik berbasis android dapat disimpulkan sebagai berikut:

a. Penggunaan aplikasi android untuk media pembelajaran rawat tanaman hidroponik dapat meningkatkan minat belajar bertanam.

b. Pembuatan aplikasi android dapat dilakukan melalui dreamweaver, javascript, dan desain dibuat dengan menggunakan Photoshop, CorelDraw, Blender.

c. Soal evaluasi sudah menggunakan model soal acak (random).

d. Akses aplikasi android di dalam perangkat mobile cukup ringan dikarenakan file yang dihasilkan saat proses build apk kecil.

e. Penambahkan soal evaluasi dapat dilakukan melalui pengeditan di control panel web.

Dari hasil penilaian validator pakar didapatkan nilai berkaitan dengan aspek Rekayasa Perangkat Lunak sebesar $82 \%$, berkaitan dengan aspek desain pembelajaran sebesar $80 \%$, dan aspek Komunikasi Visual sebesar $82 \%$.

Dari hasil penelitian memiliki beberapa kelemahan terkait produk yang dihasilkan antara lain :

a. Animasi pada aplikasi android berjalan tidak dapat bersamaan dengan suara. 
b. Tidak adanya bentuk soal selain pilihan ganda dikarenakan setelah di-publish ke dalam bentuk aplikasi android, bentuk soal selain pilihan ganda tidak dapat berjalan sebagaimana mestinya.

c. Soal kuis belum bisa menampilkan soal yang berupa gambar.

d. Menjawab soal pada kuis harus terkoneksi dengan internet.

\section{PUSTAKA}

Wibowo, H. Supriyadi, Dedih. 2017. Jurnal Ilmu Komputer dan teknologi Informasi Vol 2 No.1 : E-Learning Bercocok Tanam Hidroponik Dengan Metode Asynchronous Learning dan dynamic Intellectual Learning Berbasis Web. (online),

(http://journal.ubpkarawang.ac.id/index.php/Te knikInformatikaSistemInfor/article/view/215, diakses 5 Januari 2018)

Suhardiyanto, H. 2002. Teknologi Hidroponik. Modul Pelatihan Aplikasi Teknologi Hidroponik untuk Pengembangan Agribisnis Perkotaan. Bogor: CREATA-IPB dan Depdiknas.

Susilana, R., \& Riyana, C. (2008). Media Pembelajaran. Bandung: CV.Wacana Prima.

Alwi, H. (2003). Kamus Besar Bahasa Indonesia. Jakarta: Balai Pustaka.

Daryanto. (1993). Media Visual Untuk Pengajaran Teknik. Bandung: Tarsito.

Arsyad, A. (2011). Media Pembelajaran. Jakarta: Rajawali Pers. 